\title{
Comparison between Concentrations of Cholesterol and Progesterone of Pregnant and Non Pregnant Recipients Cattle in Studies Including Flax Seed Supplementation and Embryo Transfer
}

\author{
Mukesh Sahu $^{1 *}$, Shiv Prasad ${ }^{1}$, Sudhansu Pratap Singh ${ }^{2}$ and Avaneesh Kumar Singh ${ }^{3}$ \\ ${ }^{1}$ Department of Veterinary Gynaecology and Obstetrics, College of Veterinary and Animal \\ Sciences G. B. Pant University of Agriculture and Technology, Pant Nagar, \\ Uttarakhand, India \\ ${ }^{2}$ Department of Veterinary Gynaecology and Obstetrics, Bihar Veterinary College, Bihar \\ Animal Sciences University, Patna, Bihar, India \\ ${ }^{3}$ Department of Veterinary Gynaecology and Obstetrics, DUVASU, Mathura (U.P.), India
}

*Corresponding author

\section{A B S T R A C T}

Keywords

Cholesterol,

Conception,

Progestrone, Flax

Seed

Article Info

Accepted:

22 January 2021

Available Online:

10 February 2021
The present study was designed to observe the effect of supplementation of PUFA enriched diet on Cholesterol concentration and how it affects the progesterone concentration and conception. Flax seeds, source of PUFA of the Omega-3 family were fed @ $300 \mathrm{~g} / 100 \mathrm{~kg}$ body wt/day orally for 21 days to the animals as a supplement with routine diet. Blood sampling was done in recipient cows at $0,7,14$ and 21 days of estrous cycle. Donor $(n=6)$ and crossbred recipient cows $(n=24)$ were selected and divided into four groups viz; control (no treatment), T-1 (treatment given to recipient only), T-2 (treatment given to donor only) and T-3 (treatment given to both recipient and donor). According to results recipients reshuffles in three group, non treated non pregnant, treated non pregnant and treated pregnant and comparison done in these three groups. The Cholesterol concentration differs nonsignificantly between non treated non pregnant and treated non pregnant but differs significantly with treated pregnant $(164.19 \pm 2.05,210.90$ \pm 2.80 , and $222.81 \pm 0.79 \mathrm{mg} / \mathrm{dl}$ ) and similar result found with Progesterone concentration $(4.80 \pm 0.51,7.68 \pm 0.75$, and $8.02 \pm 0.58 \mathrm{ng} / \mathrm{ml})$. On the basis of result, it can be concluded that cholestereol and progesterone concentration vary in similar fashion in all groups and the flax seeds supplementation may helps in conception with increasing Progesterone and Cholesterol Concentration.

\section{Introduction}

In animal husbandry, artificial insemination (AI), synchronization of estrous, multiple ovulation and embryo transfer (MOET), and use of various other reproductive technology may be of great use for rapid multiplication, propagation and development of animal species (Mondal et al., 2014). To improve genetic make up of their herds and increase high pedigreed animal numbers quickly, Embryo transfer has become the most 
effective tool with scientists (Weldegebriel, 2015). In this technique, genetic contribution of both the male and female are utilized simultaneously leading to faster genetic improvement. But the demerit with technique is low conception rate like Pregnancy rates following fresh embryo transfer was $24 \%$. Embryo transfer from Indigenous donors produced $30 \%$ pregnancies while crossbred donors produced $23 \%$ pregnancies (Patel et al., 2013). Management of reproductive functions by supplementation of fat source in cattle is fairly a recent development, it affecting the dominant follicle's size, increasing the luteal phase progesterone concentration, manipulating uterine prostaglandin synthesis and improving embryo quality (Santos et al., 2008). Hence, the supplementation of polyunsaturated fatty acids (PUFA) of the Omega-3 family (e.g. eicosapentaenoic acid, docosahexaenoic acid) which can be obtained from flaxseed, sunflower, fish oil etc. is proved to be beneficial. For better conception, normal blood biochemical parameters are also essential. Therefore, in the present study, attempt has been made to evaluate the cholesterol and progesterone on supplementation of Flax seed.

\section{Materials and Methods}

The present study was conducted on Sahiwal and crossbred cattle at Instructional Dairy Farm, Nagla, G.B. Pant University of Agriculture and Technology, Pantnagar, District - Udham Singh Nagar (Uttarakhand). Animals were divided in to 04 groups as control (no treatment given to any animal), $\mathrm{T}$ 1 (treatment given to recipient only), T-2 (treatment given to donor only) and T-3 (treatment given to both donor and recipient) each containing 03 donors and 6 recipient cows. Donor animals were used repeatedly. Flax seeds were fed @ 300g/100kg body weight/day orally for 21 days to the animals as a supplement with routine diet. Blood sampling was done in all 24 recipient cows at 0 (day of starting of estrus), 7th, 14th and 21st day of estrous cycle. About $15 \mathrm{ml}$ blood without anticoagulant was collected in sterilized test tube and kept at room temperature as a slant for 1 hour for separation of blood serum. After centrifugation at $3000 \mathrm{rpm}$ for 15 minute, serum was separated and stored at $-20{ }^{\circ} \mathrm{C}$ till further analysis. The serum glucose and cholesterol of crossbred recipients was analysed using standard biochemical procedures. The progesterone estimation in samples was done by using progesterone C.T. RIA kit (M/S Beckman Coulter IM 1188) at IVRI (Nuclear Research Laboratory under Division of Physiology and Climatology), Izatnagar, Bareilly, Uttar Pradesh. Total twenty four Sahiwal embryos were transferred in reproductively sound and healthy crossbred cows. Two pregnancies were confirmed in $\mathrm{T}$ 3 group while no pregnancy was found in rest of groups. The examination of pregnancy was done per- rectally in cows on 45th day of embryo transfer. The data obtained during experimentation were analysed for mean, standard error, and coefficient of correlation. Differences between means were compared using two sample t-test and One way ANOVA (Snedecor and Cochran, 1994).

\section{Results and Discussion}

\section{Average Serum Cholesterol Concentration (mg/dl)}

The average serum cholesterol concentration in all group was not differ much on day 0but it started to increase from 7 day to day 14 and then nearly remain same. On day 14 there was significant difference was found between treated pregnant and non treated non pregnant group while non significant difference was found between treated pregnant and treated non pregnant group (Table 1 and Fig. 1). 
The mean serum cholesterol concentration of control and T-2 group found in this experiment are in agreement with reports of Kappel et al., (1984), Kumar (2002), Alameen and Abdelatif (2012), Malik (2017), Maithani (2017), however these workers reported lower values of serum cholesterol than in T-1 and T-4 groups. Ghasem Zadeh et al., (2011) reported higher concentration of mean serum cholesterol concentration in Holstein cows where cows were divided into 4 groups and fed either fish oil (256.70 $\mathrm{mg} / \mathrm{dl})$, soyabean oil $(292.00 \mathrm{mg} / \mathrm{dl})$ and both $(288.30 \mathrm{mg} / \mathrm{dl})$ than above experiment.

Table.1 Mean $( \pm$ SE) serum Cholesterol concentration $(\mathrm{mg} / \mathrm{dl})$ in non treated non pregnant, treated non pregnantand treated pregnant on $0,7^{\text {th }}, 14^{\text {th }}$ and $21^{\text {th }}$ day of estrous cycle in crossbred recipients

\begin{tabular}{|c|c|c|c|}
\hline Day & Non treated non pregnant & Treated non pregnant & Treated pregnant \\
\hline $\mathbf{0}$ & $150.37 \pm 3.07$ & $155.55 \pm 1.76$ & $166.61 \pm 2.72$ \\
\hline $\mathbf{7}$ & $168.00 \pm 2.78$ & $182.85 \pm 2.91$ & $197.07 \pm 2.75$ \\
\hline $\mathbf{1 4}$ & $164.19 \pm 2.05$ & $210.90 \pm 2.80$ & $222.81 \pm 0.79$ \\
\hline $\mathbf{2 1}$ & $161.63 \pm 2.86$ & $209.41 \pm 3.26$ & $221.82 \pm 0.27$ \\
\hline
\end{tabular}

Table.2 Mean ( \pm SE) serum progesterone concentration $(\mathrm{ng} / \mathrm{ml})$ in non treated non pregnant, Treated non pregnant and treated pregnant on $0,7^{\text {th }}, 14^{\text {th }}$ and $21^{\text {th }}$ day of estrous cycle in crossbred recipients

\begin{tabular}{|c|c|c|c|}
\hline $\begin{array}{c}\text { Day of estrous } \\
\text { cycle }\end{array}$ & $\begin{array}{c}\text { Non treated non } \\
\text { pregnant }\end{array}$ & $\begin{array}{c}\text { Treated non } \\
\text { pregnant }\end{array}$ & $\begin{array}{c}\text { Treated } \\
\text { pregnant }\end{array}$ \\
\hline $\mathbf{0}$ & $0.35 \pm 0.06$ & $0.49 \pm 0.05$ & $0.35 \pm 0.10$ \\
\hline $\mathbf{7}$ & $2.12 \pm 0.20$ & $3.26 \pm 0.44$ & $3.25 \pm 0.34$ \\
\hline $\mathbf{1 4}$ & $4.16 \pm 0.29$ & $5.82 \pm 0.68$ & $9.12 \pm 3.36$ \\
\hline $\mathbf{2 1}$ & $4.80 \pm 0.51$ & $7.68 \pm 0.75$ & $8.02 \pm 0.58$ \\
\hline
\end{tabular}

Fig.1 Mean $( \pm$ SE) serum Cholesterol concentration $(\mathrm{mg} / \mathrm{dl})$ in non treated non pregnant Treated non pregnant and treated pregnant on $0,7^{\text {th }}, 14^{\text {th }}$ and $21^{\text {th }}$ day of estrous cycle in crossbred recipients

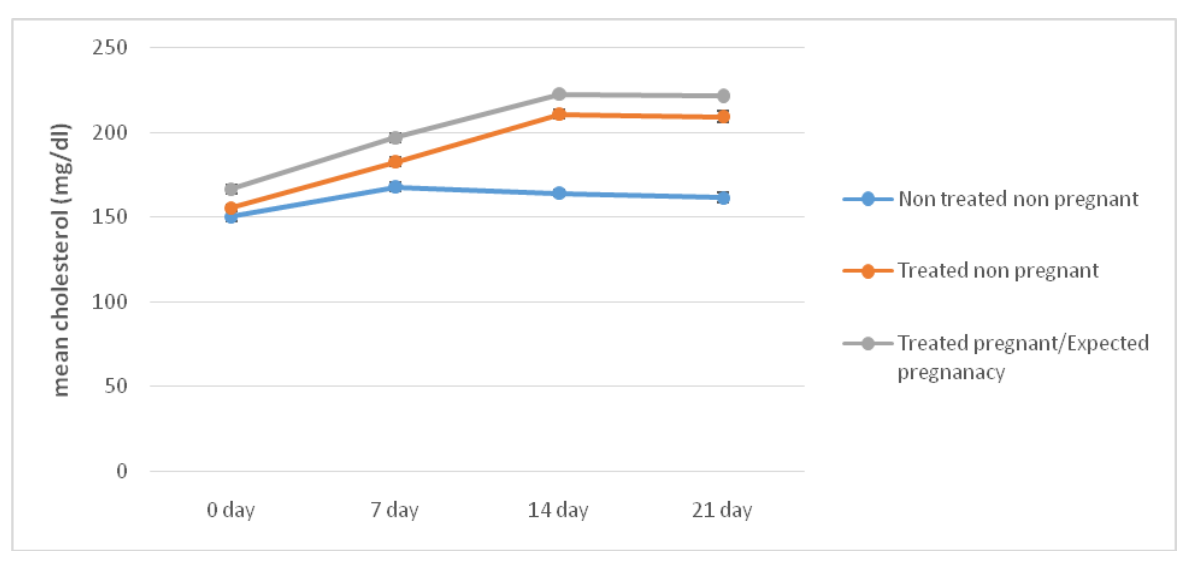


Fig.2 Mean $( \pm$ SE) serum progesterone concentration $(\mathrm{ng} / \mathrm{ml})$ in non treated non pregnant, Treated non pregnant and treated pregnant on $0,7^{\text {th }}, 14^{\text {th }}$ and $21^{\text {th }}$ day of estrous cycle in crossbred recipients

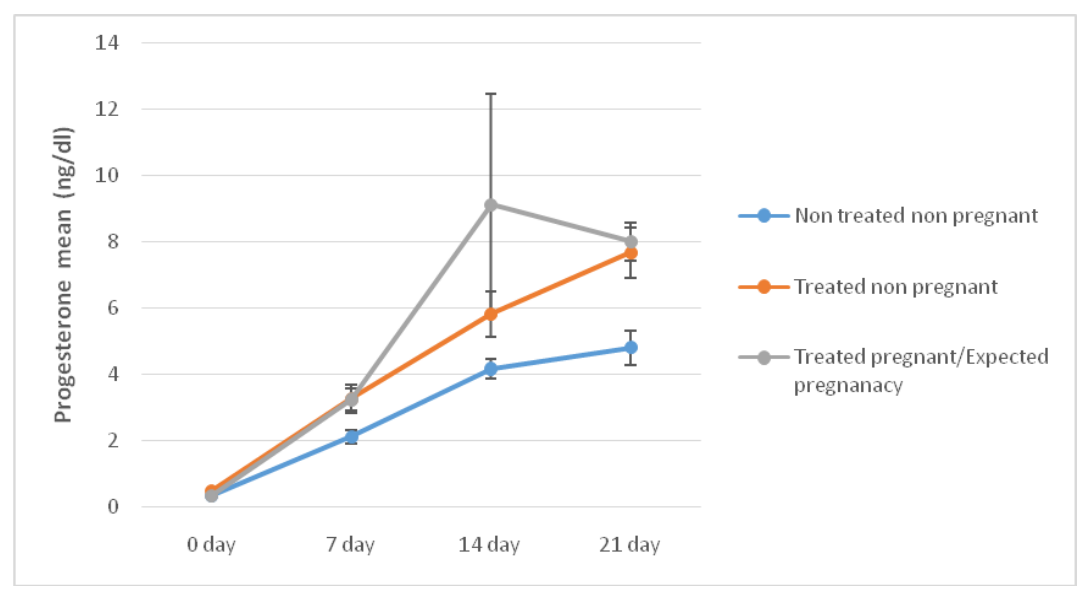

Average serum progesterone concentration (ng/dl)

The average serum progesterone concentration in all group was not differ much on day 0 but it started to increase from 7 day to day 14 and then nearly remain same. On day 14 there was significant difference was found between treated pregnant and non treated non pregnant group while non significant difference was found between treated pregnant and treated non pregnant group (Table 2 and Fig. 2).

Rajamahendran et al., (1976) have reported that progesterone level remains less than $1 \mathrm{ng} / \mathrm{ml}$ during initial days of cycle then it start to increase rapidly between 4 th to 12 th day and reaches a maximum level of $5.2 \pm 1.1 \mathrm{ng} / \mathrm{ml}$ on day 14 of the cycle. Thereafter, the level decreases to $2.6 \pm 0.6 \mathrm{ng} / \mathrm{ml}$ on day 16 and to $0.40 \pm 0.1 \mathrm{ng} / \mathrm{ml}$ on day 21 of the cycle in normal cycling animal.

In two different experiments by Cordeiro et al., (2015), it has been reported that mean serum progesterone level found on day $0(0.76 \pm 0.12$ $\mathrm{ng} / \mathrm{ml})$, day $7(4.72 \pm 0.23 \mathrm{ng} / \mathrm{ml})$, day $19(3.48$ $\pm 0.38 \mathrm{ng} / \mathrm{ml})$ and day $21(4.09 \pm 0.60 \mathrm{ng} / \mathrm{ml})$ in control group while in treated group it was found to be $0.88 \pm 0.14,4.92 \pm 0.24,5.75 \pm 0.39$ and $5.05 \pm 0.68 \mathrm{ng} / \mathrm{ml}$, respectively, when samples were taken on same days as for control group in which sunflower seeds was supplemented to beef cattle.

In present study, similar values were obtained except value on day 7 where it is towards lower side. Ghasemzadeh et al., (2011) reported higher concentration of mean progesterone concentration in Holstein cows than control $(6.96 \mathrm{ng} / \mathrm{ml})$ where cows were divided into 3 groups that were fed fish oil $(6.47 \mathrm{ng} / \mathrm{ml})$, soyabean oil $(8.30 \mathrm{ng} / \mathrm{ml})$, fish oil + soyabean oil $(9.62 \mathrm{ng} / \mathrm{ml})$. However, Nazir et al., (2013) found lower concentrations of mean serum progesterone in both control and flax seed supplemented group than value found in present study.

\section{Conception following transfer of Sahiwal embryos}

Total twenty four Sahiwal embryos were transferred in reproductively sound and healthy crossbred cows. Two pregnancies were confirmed in T-3 group, while in other groups recipient cows returned to heat.

According to above results, it might be concluded that supplementation of flax seed (PUFA) for 21 days during estrous cycle in recipient cows results into increase in 
cholesterol concentration which provide more substrate for progesterone synthesis and ultimately helps in improving conception following embryo transfer.

\section{References}

Alameen, A.O. and Abdelatif, A.M. 2012. Metabolic and endocrine responses of crossbred dairy cows in relation to pregnancy and season under tropical conditions. American-Eurasian J. Agric. and Environ. Sci., 12(8): 1065-1074.

Cordeiro, M.B., Peres, M.S., de Souza, J.M., Gaspar, P., Barbiere, F., SáFilho, M.F., MaturanaFilho, M., Dinardi, R.N., Nogueira, G.P., Mesquita, F.S. and Pugliesi, G. 2015. Supplementation with sunflower seed increases circulating cholesterol concentrations and potentially impacts on the pregnancy rates in Bosindicus beef cattle. Theriogenology, 83(9), pp.1461-1468.

Ghasemzadeh-Nava, H., Fatahnia, F. and Nikkhah, A. 2011. Effects of dietary polyunsaturated fatty acids on ovarian function and prostaglandin secretion in lactating dairy cows. Iranian Journal of Veterinary Medicine, 5(2), pp.129-135.

Kappel, L.C., Ingraham, R.H., Morgan, E.B., Zeringue, L., Wilson, D. and Babcock, D.K. 1984. Relationship between fertility and blood glucose and cholesterol concentrations in Holstein cows. American Journal of Veterinary Research, 45(12), pp.2607-2612.

Kumar, N. 2002. Studies on superovulatory response in Sahiwal and crossbred cows following human chorionic Gonadotropin (hCG) and estradiol pretreatment. PG thesis, G.B. Pant University of Agriculture and Technology, Pantnagar. U.S Nagar, Uttarakhand.

Maithani, M. 2017. Study on Tolfenamic Acid to improve conception following embryo transfer in cattle. PG thesis, G.B. Pant University of Agriculture and Technology, Pantnagar. U.S Nagar, Uttarakhand.

Malik, A. 2017. Study on FlunixinMeglumine to improve conception following embryo transfer in cattle. PG thesis, G.B. Pant University of Agriculture and Technology, Pantnagar. U.S Nagar, Uttarakhand.

Mondal, M., Baruah, K.K., and Rajkhowa, C. 2014. Application of Biotechnology for Augmentation of Productivity in Mithun (Bosfrontalis). Global Journal of Animal Scientific Research, 2 (4), pp. 357-364

Patel D.V., Chaudhari N.N., Patil S.R., Bhatol J.G., Bhalodia, S.D and Devanand C.P. 2013 Ultrasonographic elective superovulation and its responses in crossbred and zebu cattle. Indian Journal of Animal Reproduction, 34(1): 17-21.

Rajamahendran, R., Lague, P.C. and Baker, R.D. 1976. Plasma progesterone levels in cycling and gonadotropin prostaglandin treated heifers. Canadian J. Anim. Sci., 56: 37-42.

Snedecor, G.W. and Cochran, W.G. 1994. Statistical methods. 8th edn. Affiliated East. West Press, New Delhi, 13, pp.1467-1473.

Weldegebriel, D.G. 2015. A Review of Embryo Transfer Technology in Cattle. Global Journal -of Animal Scientific Research, 3(2), pp.562-575.

\section{How to cite this article:}

Mukesh Sahu, Shiv Prasad, Sudhansu Pratap Singh and Avaneesh Kumar Singh. 2021. Comparison between Concentrations of Cholesterol and Progesterone of Pregnant and Non Pregnant Recipients Cattle in Studies Including Flax Seed Supplementation and Embryo Transfer. Int.J.Curr.Microbiol.App.Sci. 10(02): 3209-3213. doi: https://doi.org/10.20546/ijcmas.2021.1002.352 